\title{
Impact of LULC change on the runoff, base flow and evapotranspiration dynamics in eastern Indian river basins during 1985-2005 using variable infiltration capacity approach
}

\author{
Pulakesh Das $^{1}$, Mukunda Dev Behera ${ }^{1, *}$, Nitesh Patidar ${ }^{2}$, Bhabagrahi Sahoo ${ }^{3}$, \\ Poonam Tripathi $^{1}$, Priti Ranjan Behera ${ }^{3}$, S K Srivastava ${ }^{4}$, Partha Sarathi Roy ${ }^{5}$, \\ PraveEn ThakUR $^{4}$, S P Agrawal ${ }^{4}$ and Y V N Krishnamurthy ${ }^{6}$ \\ ${ }^{1}$ Centre for Oceans, Rivers, Atmosphere and Land Sciences, Indian Institute of Technology Kharagpur, \\ Kharagpur 721 302, India. \\ ${ }^{2}$ Civil Engineering Department, Indian Institute of Technology Delhi, New Delhi 110 016, India. \\ ${ }^{3}$ School of Water Resources, Indian Institute of Technology Kharagpur, Kharagpur 721 302, India. \\ ${ }^{4}$ Indian Institute of Remote Sensing (ISRO), Dehradun 248 001, India. \\ ${ }^{5}$ University of Hyderabad, Hyderabad 500 046, India. \\ ${ }^{6}$ National Remote Sensing Centre, Hyderabad 500 054, India. \\ ${ }^{*}$ Corresponding author. e-mail: mukundbehera@gmail.com
}

MS received 28 September 2016; revised 18 July 2017; accepted 29 July 2017; published online 2 March 2018

As a catchment phenomenon, land use and land cover change (LULCC) has a great role in influencing the hydrological cycle. In this study, decadal LULC maps of 1985, 1995, 2005 and predicted-2025 of the Subarnarekha, Brahmani, Baitarani, Mahanadi and Nagavali River basins of eastern India were analyzed in the framework of the variable infiltration capacity (VIC) macro scale hydrologic model to estimate their relative consequences. The model simulation showed a decrease in ET with $0.0276 \%$ during 1985-1995, but a slight increase with 0.0097\% during 1995-2005. Conversely, runoff and base flow showed an overall increasing trend with 0.0319 and $0.0041 \%$ respectively during $1985-1995$. In response to the predicted LULC in 2025, the VIC model simulation estimated reduction of ET with $0.0851 \%$ with an increase of runoff by $0.051 \%$. Among the vegetation parameters, leaf area index (LAI) emerged as the most sensitive one to alter the simulated water balance. LULC alterations via deforestation, urbanization, cropland expansions led to reduced canopy cover for interception and transpiration that in turn contributed to overall decrease in ET and increase in runoff and base flow. This study reiterates changes in the hydrology due to LULCC, thereby providing useful inputs for integrated water resources management in the principle of sustained ecology.

Keywords. VIC model; land use; Mahanadi River basin; hydrograph; ILULC-DMP; decadal scale.

Supplementary material pertaining to this article is available on the Journal of Earth System Science website (http://www. ias.ac.in/Journals/Journal_of_Earth_System_Science). 


\section{Introduction}

The importance of hydrological cycle can be highlighted in the perspective of linking the two major subsystems of earth, i.e., physical and biogeochemical cycles; thus, influencing the atmospheric circulations by redistributing water and energy (Asrar and Dozier 1994). The physical system of the earth involves long-term changes in hydrological components, including precipitation, runoff, evapotranspiration, and surface and sub-surface soil moisture storage, whereas the biogeochemical system includes long-term alteration in nutrients and sediments fluxes and water quality parameters (Alcamo and Henrichs 2002; Vörösmarty et al. 2004; Alcamo et al. 2005). The physical and biogeochemical systems are linked through the cycling of water. Modification of LULC alters the fluxes of physical and biogeochemical systems and may eventually affect water, food and environmental security, e.g., a considerable reduction in the forest leads to reduced evapotranspiration and amplified runoff mainly due to reduced leaf area index and rooting depths. A reduction in evapotranspiration may lead to reduced atmospheric moisture supply and therefore less water availability through precipitation (Marengo 2006). The water, energy and chemical fluxes of earth system are integrated through hydrologic cycle and any external forcing, in particular, reference to anthropogenic activities can have a significant impact on these fluxes. Since the physical climate is very sensitive to the fluctuations in earth's radiation balance, any forcing might change the radiative heat mechanism and, consequently, the balance of natural cycles. Hence, the catchment phenomenon such as the importance of land use and land cover change (LULCC) has a great role in influencing the physical climate system, biogeochemical cycles, and the global hydrological cycle.

Quantification of the effects of LULCC in partitioning of precipitation into evapotranspiration, runoff and groundwater recharge at wide range of spatial scales have been of immense interest to hydrologists, land managers and policy makers. LULCC influences the physical properties of landscape by altering leaf area index, rooting depth, albedo and surface roughness, and thus modify the radiation, momentum and water dynamics between the atmosphere and land system (Chahine 1992; Pielke 2005). Past studies demonstrate the potential impacts of LULCC on climate, for instance, tropical region might experience more warming and drying due to deforestation (Henderson-Sellers et al. 1993; Defries et al. 2002), and considerably high cooling in higher latitudes of the northern hemisphere (Bonan et al. 1992; Lawrence et al. 2010). Studies justify the concerns about the consequences of LULCC on hydrological cycle, i.e., change in streamflow, flood intensification, groundwater depletion, changes in soil moisture and precipitation (Lorup et al. 1998; Brown 2000; Koster et al. 2004; Schilling et al. 2008; Seneviratne et al. 2010). Changes in LULC, primarily deforestation and urbanization lead to reduced evapotranspiration and groundwater recharge and increased streamflow (Bosch and Hewlett 1982; Calder 1992).

To understand and address the impact of LULCC, various hydrological models are being used, which often provide more insight into the hydrological processes. Physically distributed hydrological models allow defining the spatial variations of soil, topography, LULC and climate across the hydrological unit and, therefore, facilitate to assess the hydrologic impacts of LULCC over space and time. However, implementation of these models might be challenging due to unavailability of spatially distributed inputs, such as Leaf Area Index (LAI), albedo, radiation, precipitation and temperature. The information on the spatial distribution of LULC and associated parameters (mainly LAI and albedo) is important to capture the spatial heterogeneity of landscapes in hydrological models (Collischonn et al. 2008). The changes in a model simulated ET and runoff values are mainly governed by changes in the vegetation parameters, specifically LAI, LULC classes with higher LAI values typically have higher ET and lower runoff values. Therefore, spatiallycoalesced inputs to a hydrological model may not be appropriate for assessing impacts of LULCC. The advancement in space application has led to easy availability of distributed data by means of remote sensing at various scales and can serve as an aiding tool for the extraction of input data of the distributed hydrological models ( $\mathrm{Li}$ et al. 2009a, b; Tang et al. 2009; Wang and Qu 2009; Dietz et al. 2012; Xu et al. 2014). The variety of hydrological models that have been employed to assess the hydrologic impacts of LULCC throughout the world, includes ArcView Soil and Water Assessment Tool (AVSWAT, Arnold et al. 1998), MIKE-SHE (Abbott et al. 1986), Precipitation Runoff Modeling System (PRMS; Markstrom et al. 2015), and Variable Infiltration Capacity (VIC; Liang et al. 1994) model. Recently, Mishra (2008) 
and Aggarwal et al. (2012) have observed the significant performance of the VIC model in capturing the LULCC impact on the hydrological components. Muñoz-Arriola et al. (2009) employed VIC for assessing the hydrologic impacts of agriculture extensification under multi-scale climate conditions in Rio Yaqui Basin, Mexico. Tang et al. (2010) compared VIC simulated terrestrial water storage change (TWSC) with the Gravity Recovery and Climate Experiment (GRACE) data. In addition, VIC has also been utilized for assessing impacts of climate change (Beyene et al. 2010), for simulating surface radiative fluxes (Shi et al. 2010) and for drought monitoring (Shukla et al. 2011).

India as the second largest populated country in the world with a booming economy needs a quick assessment of hydrological processes, since the LULCC may alter hydrological and energy fluxes (evapotranspiration, runoff, soil moisture and outgoing long-wave radiations). Previous studies demonstrated the consequences of LULCC on hydrology in Indian river basins, e.g., Garg et al. (2012) observed an increase in runoff due to urbanization in the Asan River watershed of Dehradun city. Mishra (2008) observed an increase in annual streamflow of the Mahanadi River basin due to decrease in forest cover only. Patidar and Behera (2018) and Babar and Ramesh (2015) observed a net decrease in evapotranspiration due to deforestation in the Ganga River and Nethravathi River basins, respectively.

The study area comprises of four river basins of eastern India, namely, the Mahanadi $\left(144,395.04 \mathrm{~km}^{2}\right)$, Brahmani-Baitarani $(53,088.52$ $\left.\mathrm{km}^{2}\right)$, Subarnarekha $\left(26,521.45 \mathrm{~km}^{2}\right)$ and Nagavali $\left(41,975.77 \mathrm{~km}^{2}\right)$, which supports a huge population and has undergone drastic LULC changes in the past decades (Dadhwal et al. 2010; Bhagwat and Maity 2013; Behera et al. 2018). Now-a-days, these river basins are also facing an increased number of recurrent flood and drought events. Since the occurrence of these hydrological extremes could be because of the combined effect of increasing incidences of extreme precipitation and LULCC altering the total water balance of the study area, the impact of each component could be deciphered. Hence, there is a need to study the impacts of LULCC on the hydrological process components in relation to the existing climate scenario. To achieve this, the historical LULCC were studied during 1985, 1995 and 2005, and simulated the future scenario for the year 2025 using a comprehensive Land Use and Land Cover (LULC)
Modeling environment (Behera et al. 2018). The model has been developed under the Indian Space Research Organization-Geosphere Biosphere Programme (ISRO-IGBP) by the Indian Institute of Remote Sensing (IIRS), ISRO-Dehradun, India (Singh 2014; Behera et al. 2018). The VIC model used to estimate the hydrological components, and the linearized de Saint-Venant equation in the VIC Routing model was used to calibrate and validate the streamflow results (Liang et al. 1994; Lohmann et al. 1996, 1998). Details of the models can be found in various literature (Geethalakshmi et al. 2008; Dhami and Pandey 2013). Subsequently, the comparative estimates of LULCC and consequent change in the hydrological components were quantified and analyzed for the past periods such as 1985, 1995, 2005 and for the future period of 2025 . Therefore, this study utilized decadal satellitederived LULC changes to compare if the changes in the runoff, baseflow and evapotranspiration in the eastern Indian river basins are corroborative.

\section{Study area}

The study area comprising of four river basins, viz., Subarnarekha, Brahmani-Baitarani, Mahanadi and Nagavali, is situated in the eastern part of India (figure 1a). The study area henceforth shall be termed as MRB for the ease of reference. It is a rain-fed area with dry sub-humid to moist subhumid climate. The elevation in MRB ranges from 1 to $1500 \mathrm{~m}$ (figure $1 \mathrm{~b}$ ). The study area falls within Odisha and Chhattisgarh states with small portions in the Madhya Pradesh, Maharashtra and Jharkhand. The LULC of MRB is mostly dominated by agricultural land and deciduous broad leaved forest, which occupied $55 \%$ and $26 \%$ of total geographical area, respectively in 2005 (see supplementary figure S1). The Mahanadi River originates from the state of Chhattisgarh, flows eastwards through the state of Odisha and drains in to the Bay of Bengal. The total length of the Mahanadi from its origin to confluence at the Bay of Bengal is about $851 \mathrm{~km}$. The length of the other three rivers, Subarnarekha, Brahmani and Baitarani are about $395 \mathrm{~km}, 480 \mathrm{~km}$ and $260 \mathrm{~km}$, respectively (figure 1). During their traverses, a number of tributaries join the rivers on both the flanks with 14 major tributaries, of which 12 tributaries join in the upstream of the Hirakud reservoir on the Mahanadi and two in the downstream. Various dams, irrigation projects, and barrages exist in the basin; the most prominent of which is the largest 

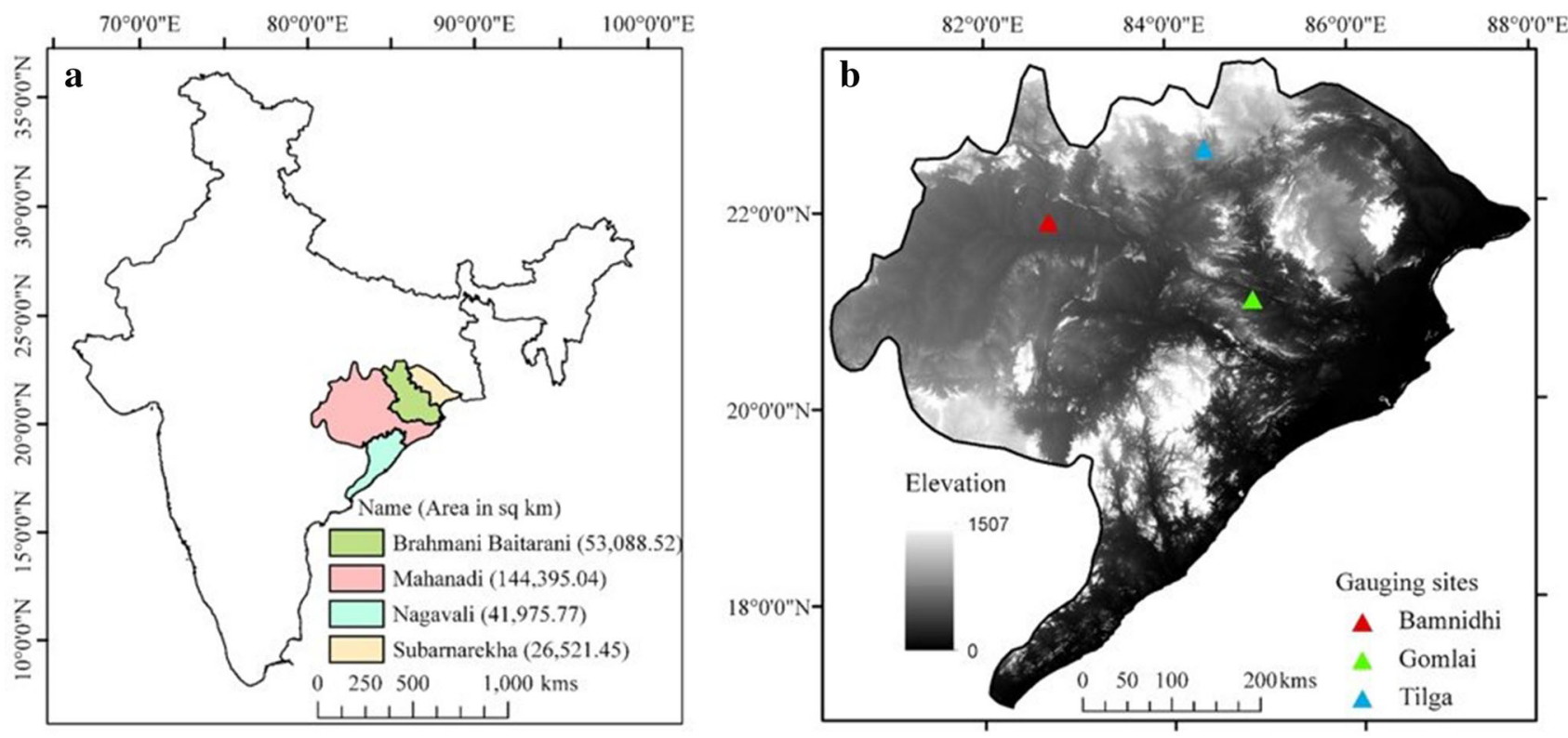

Figure 1. (a) Study area showing Mahanadi and adjoining River basins (MRB) with (b) altitude map and the discharge locations of Gomlai, Bamnidhi and Tilga.

reservoir $\left(746 \mathrm{~km}^{2}\right)$ in Asia, the Hirakud Dam. The average annual discharge in the Mahanadi is $1895 \mathrm{~m}^{3} / \mathrm{s}$ with a maximum of $6352 \mathrm{~m}^{3} / \mathrm{s}$ during the Indian summer monsoon (June-September). The annual average rainfall in the study area is $1360 \mathrm{~mm}$, of which $86 \%(1170 \mathrm{~mm})$ is contributed by the summer monsoon (see supplementary figure S2). The temperature ranges from 4 to $12^{\circ} \mathrm{C}$ in winter to a maximum of 42 to $45.5^{\circ} \mathrm{C}$ in May. The main soil types in the study basin are loamy, clayey, clay and loamy-skeletal.

\section{Methodology}

To find the hydrologic response due to LULCC, the decadal LULC maps derived from satellite imagery (1985, 1995, 2005 and predicted-2025), soil map gathered from NBSS \& LUP (Indian National Bureau of Soil Survey and Land Use Planning) and daily climate data gathered from the IMD (India Meteorological Department) for the study site (Behera et al. 2018). The LULC maps were prepared using visual interpretation technique with good accuracy along with the predicted LULC map. For calibration and validation, the daily discharge data for the gauging sites have been collected from the India-WRIS database (India-wris.nrsc.gov.in). The LULC maps were generated at 1:50,000 scale using Landsat MSS (1, 2 and $3 ; 60 \mathrm{~m}$ ) for the year 1985 and TM (4 and 5; $30 \mathrm{~m}$ ) for the years 1995 and 2005, which were accessed from Earth Explorer data portal (https://earthexplorer.usgs.gov/; Roy et al. 2015). The LULC modeling was carried out at a spatial resolution of $250 \mathrm{~m}$ (Behera et al. 2018). The soil map was collected as vector data, which was converted into raster data at $250 \mathrm{~m}$ pixel resolution. The resolution of climate data collected from IMD was 1 and $0.5^{\circ}$ for temperature and precipitation, respectively. The VIC model was run with a grid cell of $0.25^{\circ}$ appending the area of each LULC in the grids (Bhattacharya et al. 2013). The methodology flowchart is given in supplementary figure S3.

\subsection{The ISRO-IGBP LULC model (ILULC-DMP v1.0)}

The ISRO-IGBP Land Use Land Cover Change Dynamics Modeling Platform (ILUCC-DMP) is a macroscale LULC model. It is developed under the concept of set of classical spatial interactive regions that allocate activity among the competing region (White et al. 2012). Regression framework is designed to access spatial dependency using two basic approaches by developing models that are complex and calculating the distance between various sample points. This model consists of a combination of three modeling techniques of regression: Logistic Regression, Linear Regression and Neural Regression. The ILUCC-DMP model takes the LULC maps and drivers as the spatial and demands as non-spatial inputs for future scenario 
prediction (Behera et al. 2018). The spatial allocation of demand area depends on the location suitability demand condition, which is constrained by the defined decision rules in the form of location specific land use types. The location specific land use type decision rules include the migration order and the class inertia. The migration order defines the preference in the type of land cover conversion and class inertia defines the rigidity of each land cover to change. For accounting the effect of neighborhood, window size $3 \times 3$ and $5 \times 5$ kernels matrix were available.

For predicting the LULC of 2025, the past two decadal (1985, 1995 and 2005) LULCCs were studied. Different driver data including the topographic (elevation, slope, aspect; slope and aspect were derived from the SRTM DEM data, 90 $\mathrm{m}$ ), climatic (temperature and precipitation, India Meteorological Department data, $0.5^{\circ}$ ), edaphic (soil depth, vector data obtained from National Bureau of Soil Survey and Land Use Planning) and socio-economic (number of households, population, working population, literacy, sex ratio, drinking water facility, medical facility, total road length; taluk level vector data obtained and collected from various sources as census and local administrative offices) were added. In addition, to add the proximity influence, the distance to various parameters was derived such as distance to forest, water body, drainage and built-up. For modeling all the data were appended into vector grid (cell size $250 \mathrm{~m}$ ) to remove the variations in spatial scale of different input data and extension error. It again reduces the small scale LULC heterogeneity. The majority class in each grid was appended using the zonal statistics algorithm in ERDAS Imagine software. The vector grids were then converted into raster as inputs in the model. To calibrate the model parameters, the past LULCs (1985 and 1995) were used to model the LULC of 2005, applying logistic regression. The model prediction accuracy was computed comparing each pixel with the visually interpreted LULC of 2005. Using the calibrated parameters, the LULC for the year 2025 was predicted. Details of model description, input parameters defined for predicting the LULC map of 2025 can be found in Behera et al. (2018).

\subsection{The VIC hydrological model}

The variable infiltration capacity (VIC) hydrological model was used in this study to assess the hydrologic impacts of LULCC in MRB. It is a macro-scale level semi-distributed hydrological model developed at the University of Washington, USA (Liang et al. 1994). The VIC model uses empirical approximations to simulate hydrological processes of evapotranspiration, infiltration and runoff, but possesses a physically-based component to represent the exchanges of latent and sensible heats with the atmosphere. The superior aspects of VIC over the other models are: (a) its unique representation of sub-grid heterogeneity in soil moisture storage, evaporation, and runoff generation (Zhao et al. 1980), and (b) base flow parameterization, which occurs from a lower soil moisture zone as a nonlinear recession (Dumenil and Todini 1992). It takes into account the vegetation characteristics, such as Leaf Area Index (LAI), albedo, minimum stomatal resistance, architectural resistance, roughness length, relative fraction of roots in each soil layer, and displacement length (in case of LAI, Gao et al. 2009). The Penman-Monteith equation (1948) is used for estimating the evapotranspiration, which is the sum of weighted evaporation and transpiration from the vegetation cover, and evaporation from the bare soil cover according to their occurrence in a grid cell. The model considers the fractional coverage of soil types in each grid and then characterizes the behaviour of seasonal rainfall infiltration, diffusion, moisture content, surface and sub-surface runoff for each grid. The VIC simulates non-uniformly distributed runoff in each grid cell using a stand-alone routing model that solves the linearized de Saint-Venant equation (Lohmann et al. 1996, 1998). This surface runoff and base flow are transported first to the outlet and then into the river network, considering the one way flow from grid to outlet. The discharge at the basin outlet is calculated based on linearized de Saint-Venant equation assuming the unidirectional flow in a grid cell. Details on the VIC in conjunction with the routing model can be found in Liang et al. (1994) and Lohmann et al. (1996).

\subsection{Data input to the VIC model}

The implementation of the VIC model for hydrological modeling comprises of characterization of soil, topography and vegetation with meteorological forcing. The spatial distribution of these inputs was defined by dividing the study domain into 394 square grids of size $0.25 \times 0.25$ degree. The elevation and slope of each grid cell were 
derived from the Shuttle Radar Topography Mission (SRTM) digital elevation model (DEM). Soil texture of each grid cell was extracted from the soil texture map developed by NBSS \& LUP. The hydraulic properties of each soil type, such as, saturated hydraulic conductivity, porosity, field capacity and wilting point were derived using the soil hydraulic properties index given by Cosby et al. (1984). In addition to this, soil parameters, viz., soil layer depths $\left(\mathrm{d}_{1}\right.$ and $\left.\mathrm{d}_{2}\right)$, infiltration curve parameter $\left(b_{i}\right)$, sub-surface flow parameters (Ds and $W_{s}$ ) were derived using the manual calibration of the model utilizing the guidelines given by Gao et al. (2009).

The vegetation parameterization of the VIC model typically includes fractional coverage of each LULC within the grid cell, monthly LAI and albedo, flag for presence/absence of canopy, displacement height, roughness length and stomatal and architectural resistances. Among these parameters, LAI is the most sensitive parameter to alter the water balance during the VIC simulation. In the present study, MODIS LAI data product (MCD15A2, 2005) with $500 \mathrm{~m}$ resolution was used to derive the monthly LAI of each LULC. Further, MODIS quality flags were used to extract the cloud-free pixels for each month. These quality pixels were then filtered through a mask of homogeneous LULC patches. Monthly LAI values for each LULC were considered as the aggregate of the filtered LAI pixels. The albedo values corresponding to each LULC were computed using the same procedure as that of the LAI. The values of rest of the parameters were derived from the LDAS 8th database and MM5 terrain dataset (http://ldas.gsfc.nasa.gov/LDAS8th/ MAPPED.VEG/web.veg.monthly.table.html).

The daily meteorological forcing of maximum temperature, minimum temperature and precipitation for the year 1976-2005 were used in the VIC model for hydrological simulation. An interpolated $1^{\mathrm{O}}$ grid daily temperature dataset and $0.5^{\circ}$ grid rainfall dataset prepared by IMD, Pune was used in the study. In order to minimize the effect of initial soil moisture conditions input to the VIC model, the first year (1976) of model simulation was kept reserved for model spin-up.

\subsection{Calibration and validation of the VIC model}

Calibration of the VIC model is typically performed by coupling the VIC model with a simple routing model developed by Lohmann et al. (1998), wherein each grid cell works as a node in the channel network. The cumulative runoff and baseflow were convolved with the rainfall, which are, represented by a Unit Hydrograph (UH). The output from each grid cell contributing to the channel network is then routed using the linearized de Saint-Venant's equation. It assumes that all the runoff generated from a cell travels in one single direction depending on the $\mathrm{D} 8$ algorithm. The routing model version 1.0 was used in this study. The routing model requires six input files, namely: (i) fraction file, (ii) flow direction file, (iii) flow velocity file, (iv) Xmask file, (v) station location file, and (vi) UH file. The fraction file defines the area fraction of each grid cell that flows into the basin being routed. The flow direction file defines the direction of flow for each grid. The flow velocity, diffusion and Xmask files contain the information of velocity, flow diffusion, cell size (in meters), respectively. For flow direction file, the input STRM DEM data was used to calculate the flow direction of each grid cell at $0.25^{\circ}$ resolution. The station location file defines the location of basin outlet prepared by defining the location of the streamflow gauging station on the flow direction file. The grid cell impulse function is defined through the UH file.

The soil parameters which cannot be readily determined from soil data are typically tuned during the VIC model calibration (Yuan et al. 2004). In the present study, we derived the calibrated values for soil layer depths $\left(\mathrm{d}_{1}\right.$ and $\left.\mathrm{d}_{2}\right)$, infiltration curve parameter $\left(b_{i}\right)$ and subsurface flow parameters $\left(D_{s}\right.$ and $\left.W_{s}\right)$, where $D_{s}$ is the fraction of $D_{\text {smax }}$ (maximum velocity of baseflow) in which the nonlinear baseflow begins and $\mathrm{W}_{\mathrm{s}}$ is the fraction of maximum soil moisture where nonlinear baseflow begins. The VIC simulated runoff is routed for three river sites as Bamnidhi $\left(82^{\circ} 42^{\prime} 24.064^{\prime \prime} \mathrm{E}, 21^{\circ} 54^{\prime} 7.923^{\prime \prime} \mathrm{N}\right)$, Tilga $\left(84^{\circ} 24^{\prime} 56^{\prime \prime} \mathrm{E}, 22^{\circ} 37^{\prime} 22^{\prime \prime} \mathrm{N}\right)$ and Gomlai $\left(84^{\circ} 54^{\prime}\right.$ $\left.24^{\prime \prime} \mathrm{E}, 21^{\circ} 5^{\prime} 0^{\prime \prime} \mathrm{N}\right)$ gauging stations for the years 1996-2000 for calibrating the soil parameters and 2001-2005 for validation at monthly time steps (figure 2). The simulated streamflow is compared with the observed streamflow provided by the Central Water Commission (CWC), India. The NashSutcliffe efficiency $\left(E_{f}\right)$, relative error $\left(E_{r}\right)$, and coefficient of determination $\left(r^{2}\right)$ were used to test the efficiency of the VIC model (Nash and Sutcliffe 1970). $E_{f}$ and $E_{r}$ were calculated using the given formula: 

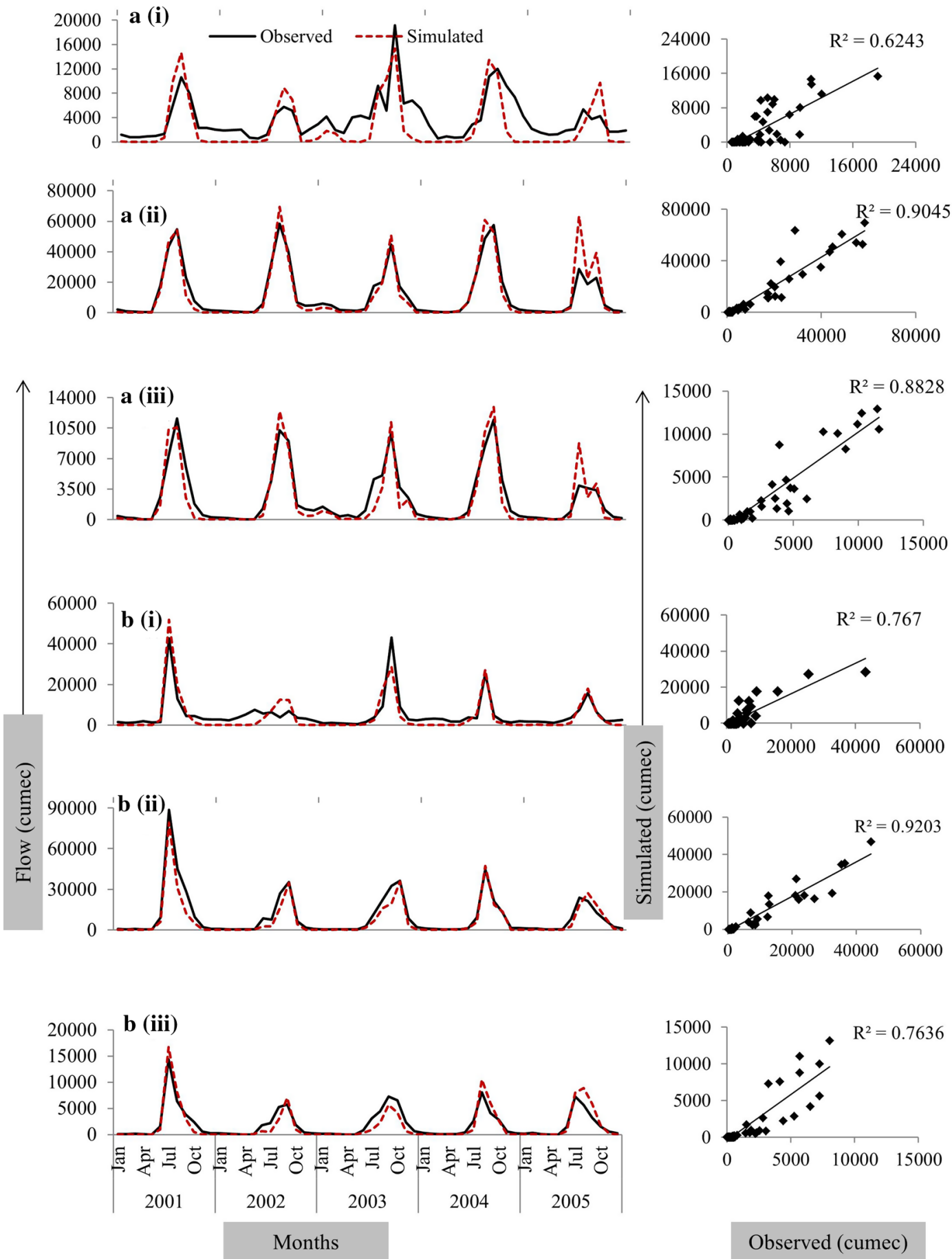

Observed (cumec)

Figure 2. Monthly hydrographs and corresponding scatter plots of (a) calibration during 1996-2000 and (b) validation during 2001-2005 showing agreement between observed and simulated streamflow at (i) Bamnidhi, (ii) Gomlai, and (iii) Tilga gauging sites. (Note: The legend and x-axis scale of all hydrographs are same.)

$$
\begin{aligned}
& E_{f}=1-\frac{\sum_{i=1}^{N}\left(Q_{\bmod , i}-Q_{\mathrm{obs}, i}\right)^{2}}{\sum_{i=1}^{N}\left(Q_{\mathrm{mod}, i}-\overline{Q_{\mathrm{obs}, i}}\right)^{2}} \\
& E_{r}=\left(\overline{Q_{\bmod }}-\overline{Q_{\mathrm{obs}}}\right) / \overline{Q_{\mathrm{obs}}}
\end{aligned}
$$

where $Q_{\bmod , i}=$ monthly modeled streamflow for month; $Q_{\mathrm{obs}}=$ monthly observed streamflow for month; $N=$ number of months; and $\bar{Q}_{\bmod }$ and $\bar{Q}_{\text {obs }}$ are the mean of the monthly modeled and observed stream flows, respectively. When $E_{f}=$ 1.0, the model perfectly predicts the observations.

VIC assesses and evaluates basin hydrology in response to long term land cover changes, and simulates naturalized flows ignoring the human 
Table 1. LULC change area statistics (in \%), (-) sign indicates loss.

\begin{tabular}{lrrr}
\hline & \multicolumn{3}{c}{ Change duration } \\
\cline { 2 - 4 } LULC types & $1985-1995$ & $1995-2005$ & $2005-2025$ \\
\hline Aquaculture & 13.89 & 142.68 & 66.83 \\
Barren land & -4.90 & -6.69 & -12.09 \\
Built-up & 9.97 & 6.11 & 14.38 \\
Cropland & 0.48 & 0.02 & 0.54 \\
Deciduous broad leaved forest & -1.09 & -0.37 & -1.50 \\
Fallow land & -2.80 & 0.14 & -2.82 \\
Mixed forest & -2.54 & -0.37 & -3.05 \\
Mangrove & -9.95 & -1.51 & -13.27 \\
Plantation & 0.47 & 2.46 & 2.74 \\
Saltpan & 0.00 & 4.55 & 4.35 \\
Scrubland & -1.75 & -0.57 & -2.36 \\
Waterbody & 4.55 & 0.38 & 4.41 \\
Waste land & 10.16 & -5.21 & 2.28 \\
\hline
\end{tabular}

induced effects. Therefore, the effect of upstream reservoirs and dams in the study area were not incorporated, which added biases in the calibration and validation (Dadhwal et al. 2010). The bias, root mean square error and mean absolute error were derived to address the degree of disagreement observed in the study.

\section{Results and discussion}

\subsection{LULC change and prediction}

A total of 13 classes were mapped in 1985, 1995 and 2005 for the basin as aquaculture (AQ), barren land (BL), built up (BU), crop land (CL), deciduous broad leaved forest (DBF), fallow land (FL), grass land (GL), mangrove (MG), mixed forest (MF), plantation (PL), salt pane (SP), shrub land (SL), water body (WB) and waste land (WL; supplementary figure S1). It can be seen that the CL occupied mostly in the eastern and western parts of the basin; however, the forest classes dominated the upper and central regions of the basin. Out of the total geographic area, the maximum area (nearly $56 \%$ ) was covered by CL in all the three years (Behera et al. 2018; supplementary figure S1). Among the forest classes, DBF occupied the maximum area $(\sim 26 \%)$. MG, BL and SP occupied small fractions of basin area in these three years $(<1 \%)$. On an average, MF and SL occupied nearly 4 and $5 \%$ of the total geographic area, respectively. We observed overall decreases in the forest classes for the study periods and increases in BU and CL classes for the basin (see supplementary figure S1e; table 1). Among the forest classes, the maximum decrease was observed in DBF with $1.09 \%$ followed by MF (2.54\%) during 1985-1995; although, this rate was decreased to $0.37 \%$ during $1995-2005$ for both the classes. Similar trends were also observed for SL and MG classes, which were lost by 1.75 and 9.95\%, respectively during 1985-1995; whereas 0.57 and $1.51 \%$ during $1995-2005$. On the contrary, fallow land was decreased by $2.80 \%$ during $1985-1995$; but increased by $0.14 \%$ during $1995-2005$. For both these periods, BL showed a decreasing trend with 4.90 and $6.69 \%$, respectively. Conversely, the maximum increase in area was observed for CL with an overall increase of $0.48 \%$, followed by BU with an area of $9.97 \%$ during 1985-1995. However, during 1995-2005, the rate of cropland and BU expansion reduced to 0.02 and $6.11 \%$ (see supplementary figure S1e; table 1). The change in AQ observed as $13.89 \%$ during 1985-1995, which increased to more than 100\% during 1995-2005. During 1985-1995, WB increased by $4.55 \%$, whereas, during $1995-$ 2005 , this increment reduced to $0.38 \%$.

In predicting the LULC of 2005, majority of the drivers were observed highly significant, which were again used for further modeling. We observed satisfactory level of accuracy of modeled LULC w.r.t the observed LULC in 2005 showing an overall accuracy of $98 \%$ with a Kappa value of 0.97 (Behera et al. 2018). Using the significant drivers and the spatial as well as non-spatial policies and restrictions, the LULC for 2025 was predicted with the calibrated parameters. The land use area predicted by the model for the year 2025 showed a similar change pattern observed during 1985 to 2005 , where BU and CL areas were increased, reducing the forest cover. The total area for BU and CL 
were predicted to be 1.71 and $56.23 \%$, respectively in 2025. The forest classes such as DBF, MF and MG comprised of $25.65,3.97$ and $0.06 \%$ of the total basin area, respectively (Behera et al. 2018). Maximum decrease was predicted for DBF as $1.50 \%$ followed by a loss of $3.06 \%$ in MF during 20052025. The maximum area increase predicted in CL with $0.54 \%$ followed by $14.38 \%$ in BU (see supplementary figure S1e; table 1). An increase in WB, PL and WL was also observed with an increase in area of $4.41,2.75$ and $2.28 \%$, respectively.

The results revealed that the overall LULCC of the basin showed a reverse trend for forest and cropland classes, i.e., decreasing forests and increasing croplands. Expansion of cropland, built up and water body was at the expense of deforestation and loss of scrubland. A series of changes due to dam and reservoir construction led to deforestation and cropland conversions. A large area deforestation was observed in constructing the Hasdeobango reservoir (refer to India WRIS at http://india-wris.nrsc.gov.in/wrpinfo/index.ph $\mathrm{p}$ ?title $=$ Dams $\backslash$ in $\backslash$ Chhattisgarh for the list of construction of various reservoirs). However, food demand due to escalating population in the basin along with sufficient water availability from canal irrigation led to extensive agricultural practices at the cost of deforestation.

\subsection{Impact of LULC change on hydrological water balance}

Here, we used a delta approach of assessing hydrologic impacts of LULCC in which the model simulations were performed for each LULC scenario by keeping climate data (of the year 2005) invariant (Mao and Cherkauer 2009; Wagner et al. 2013). These simulations helped in identifying the effects of LULCC on ET, baseflow and surface runoff. Due to the easy and accurate measurement of streamflow than evapotranspiration and baseflow, the field measured streamflow is generally used for calibration and validation of the VIC hydrological model. In the present study, preand post-calibrated monthly streamflow for the years 1996-2005 were compared with the observed naturalized streamflow at three gauging sites at Bamnidhi, Tilga and Gomlai (figure 2). After calibration, the simulated streamflow was validated with the observed data at all the three gauging sites. The pre- and post-calibrated values of model parameters are given in table 2. Considering the
Table 2. Parameter calibration through routing model (according to soil type).

\begin{tabular}{lccl}
\hline Parameter & $\begin{array}{c}\text { Initial } \\
\text { value }\end{array}$ & $\begin{array}{c}\text { Calibrated } \\
\text { value }\end{array}$ & $\begin{array}{l}\text { Valid } \\
\text { range }\end{array}$ \\
\hline $\mathrm{D}_{\mathrm{s}}$ & 0.001 & 0.1 & $0-1$ \\
$\mathrm{~b}_{\mathrm{i}}$ & 0.2 & 0.1 & $0-0.4$ \\
$\mathrm{~W}_{\mathrm{s}}$ & 0.9 & 0.6 & $0-1$ \\
Soil depth 1 & 0.3 & Variable & $0.1-1.5$ \\
Soil depth 2 & 0.7 & 0.6 & $0.1-1.5$ \\
\hline
\end{tabular}

Table 3. Statistical parameters of calibration and validation at three gauging sites.

\begin{tabular}{lrrr}
\hline & Gomlai & Tilga & Bamnidhi \\
\hline (a) Calibration (2005) & & & \\
RMSE & 510.25 & 231.39 & 430.86 \\
MAE & 104.59 & 26.35 & 76.51 \\
Bias & 8.79 & 9.51 & 42.55 \\
$r^{2}$ & 0.90 & 0.88 & 0.62 \\
$E_{f}$ & 0.86 & 0.83 & 0.40 \\
$E_{r}$ & -0.02 & -0.13 & -0.15 \\
(b) Validation & & & \\
RMSE & 407.49 & 319.85 & 371.30 \\
MAE & 86.07 & 33.22 & 90.14 \\
Bias & 68.17 & -2.34 & 35.81 \\
$r^{2}$ & 0.92 & 0.76 & 0.77 \\
$E_{f}$ & 0.92 & 0.59 & 0.79 \\
\hline
\end{tabular}

default parameters, a poor agreement was observed between the pre-calibrated and observed streamflow with $r^{2}=0.36, E_{f}=0.22$ and $E_{r}=-0.24$. However, significant improvement in the model performance was observed after manual calibration with a maximum and minimum $r^{2}$ of 0.90 (Gomlai) and 0.62 (Bamnidhi) with highest efficiency $\left(E_{f}\right)$ of 0.86 and error $\left(E_{r}\right)$ of -0.02 at Gomlai (table 3 ). The validated streamflow also showed good agreement with the highest $r^{2}$ values of 0.92 with $E_{f}$ of 0.92 and $E_{r}$ of -0.22 at Gomlai. These results reveal that the efficiency of the VIC model is well accepted in the current study.

The bias, root mean square error and mean absolute error were derived during calibration and validation for the gauging sites to primarily address the effects imposed due to the upstream reservoir, dam and man-made artificial structures (table 3). During calibration, we observed positive biases in all gauging sites which were moderate in Gomlai (8.79) and Tilga (9.51), and high at Bamnidhi (42.55). In validation, high positive biases observed both in Gomlai and Bamnidhi, and low negative 

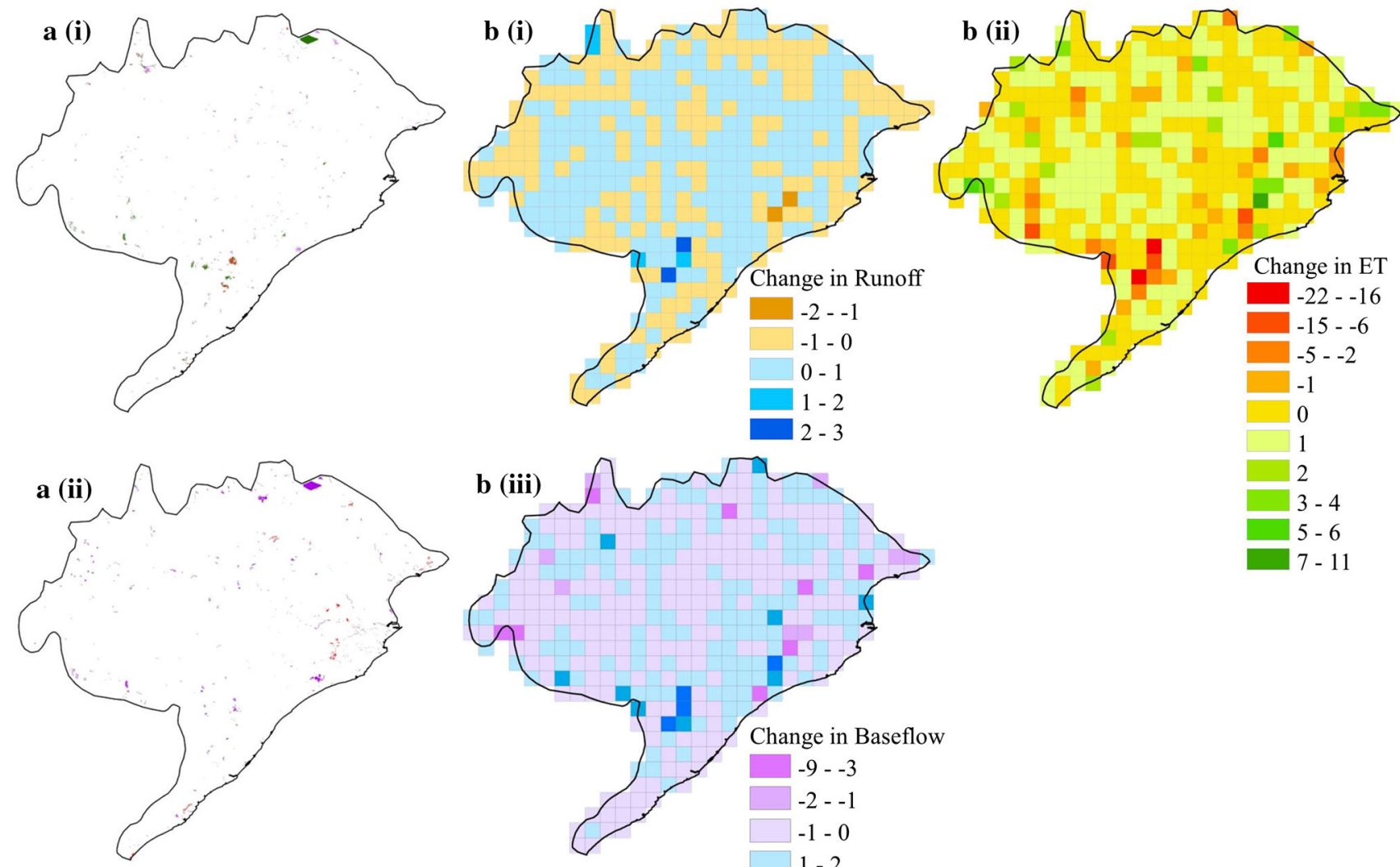

Mixed forest (MF) Built-up (BU)

Shrub land (SL) $\quad$ Crop land (CL)

Deciduous broad leaved forest (DBF)

Figure 3. (a) LULCC (i) loss and (ii) gain. (b) Change in hydrological variables (i) evapotranspiration (mean -0.2 ; SD 2.08); (ii) runoff (mean 0.06; SD 0.31) and (iii) baseflow (mean 0.06; SD 1.64) during 1985-1995 (unit in mm).

bias at Tilga. The gauging sites were not influenced by the artificial water flow except Bamnidhi, for which the corresponding bias could be attributed to the reservoir discharge measures, where positive bias shows higher water discharge and vice-versa.

The mean annual precipitation varied with a maximum of $860.68 \mathrm{~mm}$ to a minimum of $22.46 \mathrm{~mm}$ (see supplementary figure S2). The upper eastern coastal part of the study area received more precipitation than the rest, whereas the lower coastal, western and middle parts received moderate precipitation. The spatial and seasonal patterns of the simulated baseflow and runoff were similar to precipitation, revealing that the areas receiving higher precipitation generate higher runoff and baseflow (figures $3,4,5$ ). The decadal change in the hydrologic variables due to LULCC revealed that the change in ET, runoff and baseflow are the maximum during 2005-2025 with 0.09, 0.05 and $0.08 \%$, respectively (table 4; figure 6 ). To estimate the impact of percent LULCC on the percent change in these hydrological variables, a correlogram analysis was carried out (figure 7). In figure 7, the correlation coefficient, $r>0$ shows a positive impact of a specific LULCC (\%) on the change (\%) of a particular hydrological variable considered herein and vice-versa. Considering $|r|>0.5$ as the criterion for significant correlation, it can be surmised from figure 7 that the LULCC of SL, MG, MF, FL, DBF, $\mathrm{BL}$ and $\mathrm{AQ}$ have positive impacts on ET; whereas WB, SP, CL and BU have negative impacts. Similarly, WL, WB, CL and BU have positive impacts on the runoff generation; whereas SL, MG, MF, FL, $\mathrm{DBF}, \mathrm{BL}$ and AQ have negative impacts. On baseflow generation, WB, SP, CL and BU have positive impacts; and SL, MG, MF, FL, DBF, BL and AQ have negative impacts. This analysis reveals that almost all the LULCs responsible for increasing the ET loss are interacting negatively with the basinscale runoff generation. Similarly, all the LULC responsible for decreasing the ET are increasing the baseflow contribution.

An overall decrease in ET with increase in runoff and baseflow was observed for the study period 

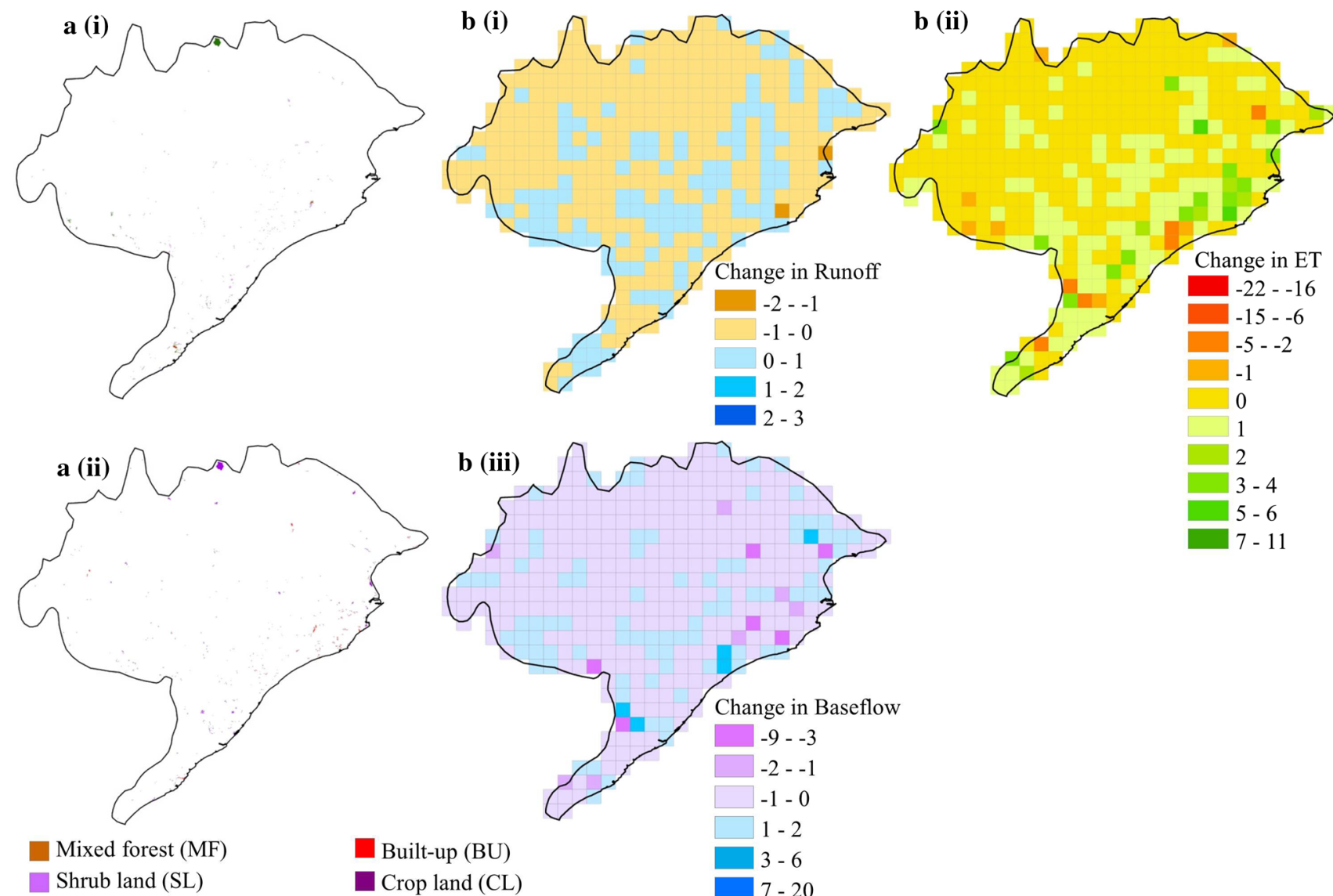

Mixed forest (MF)

Shrub land (SL)

Deciduous broad leaved forest (DBF)

Built-up (BU)

Crop land (CL)

Figure 4. (a) LULCC (i) loss and (ii) gain. (b) Change in hydrological variables (i) evapotranspiration (mean 0.08; SD 0.78); (ii) runoff (mean -0.01; SD 0.14) and (iii) baseflow (mean -0.1; S.D. 0.73) during 1995-2005 (unit in mm).

from 1985-2005. This could be attributed to an overall forest loss of $1.69 \%$ during the period. The decrease in ET was prominent during 1985-1995 with an increased runoff and baseflow and could be attributed to higher deforestation rate with a loss of nearly $771 \mathrm{~km}^{2}$ DBF and $286 \mathrm{~km}^{2} \mathrm{MF}$. However, a slight increase in ET with a decrease in runoff and baseflow during 1995-2005 could be attributed to a lower deforestation rate with higher rate of plantation in the basin. The higher deforestation during 1985-1995 led to less canopy evaporation since the canopy cover reduced with a decrease in LAI leading to decreased interception and transpiration.

The conversion of forest to crop, shrub and plantation led to decrease in surface roughness which ultimately resulted in increasing runoff due to decreased basin storage. Additionally, the absence of deep rooting system due to deforestation and conversion of untilled land or other perennial cover crops to annual row crops led to less consumption of groundwater that increased the baseflow (figure 8). Past studies have reported increased baseflow due to deforestation which led to decrease in both interception and dry season transpiration (Zhang and Schilling 2006; Favreau et al. 2009). Schilling (2005) observed an increase in baseflow due to increased intensity of row crops in Iwoa. Mishra (2008) and Dadhwal et al. (2010) also observed an increase of streamflow with $4.53 \%$ at Mundali outlet of the Mahanadi River basin as a result of decreasing ET. Bhattacharya et al. (2013) observed higher runoff in cropland area for Chambal River basin in India using the VIC model.

Table 5 shows the seasonal change of monthly ET, runoff and baseflow at basin-scale during 1985-2025, respectively. Table 5(i) shows that the monthly ET during 1985, 1995, 2005 and 2025 ranges from $18.30-113.36,18.35-113.25,18.35-$ 113.24 and $18.35-113.07 \mathrm{~mm}$, respectively, with mean ( \pm standard deviation) of $62.18( \pm 34.98)$ $62.17( \pm 34.93), 62.17( \pm 34.92)$ and $62.19( \pm 34.84)$ $\mathrm{mm}$, respectively. Irrespective of the years, the minimum and maximum ET losses occurred during the months of April and July, respectively. 

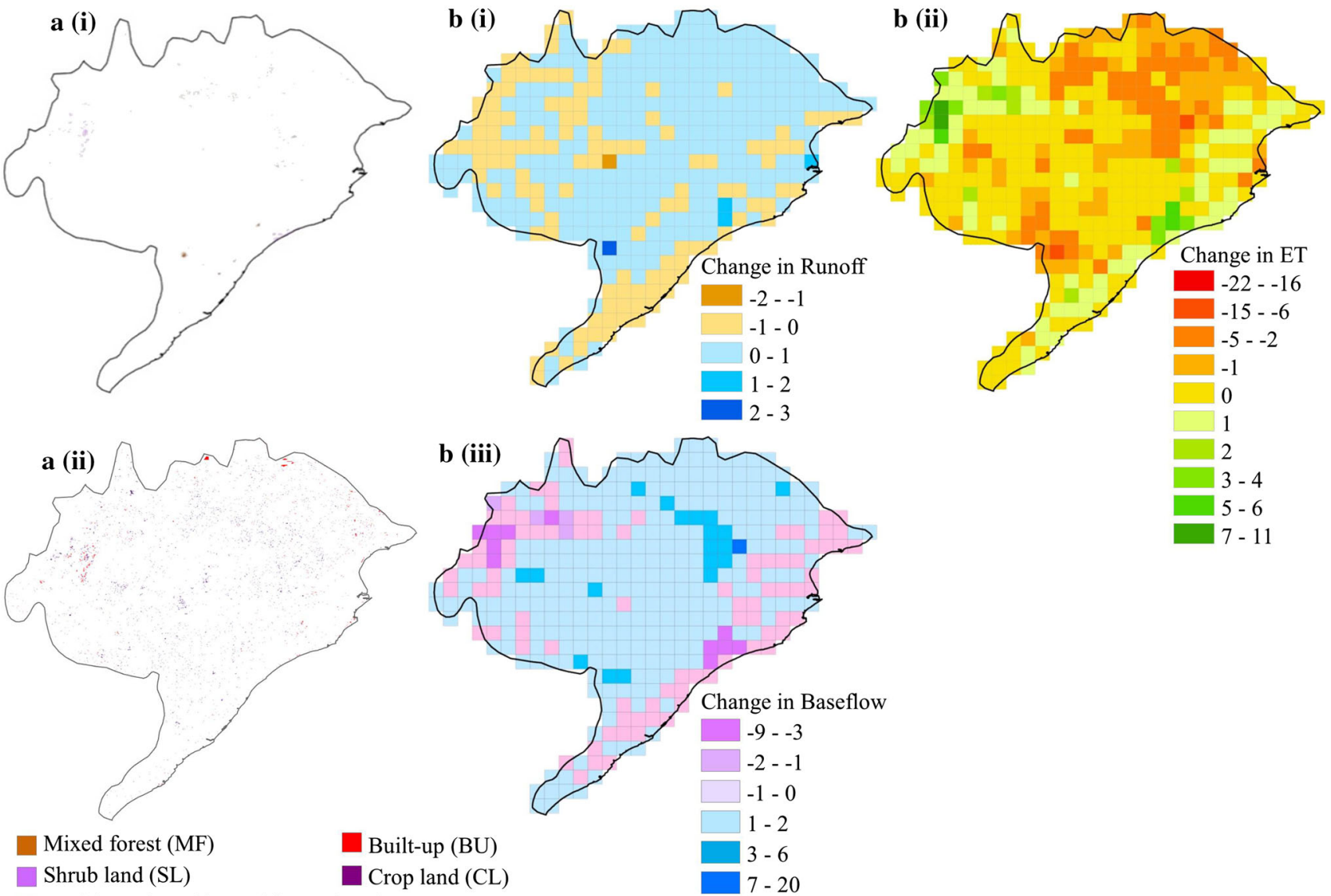

Mixed forest (MF)

Built-up (BU)

Shrub land (SL)

Deciduous broad leaved forest (DBF)

Figure 5. (a) LULCC (i) loss and (ii) gain. (b) Change in hydrological variables (i) evapotranspiration (mean -0.65; SD 1.59) (ii) runoff (mean 0.09; SD 0.25) and (iii) baseflow (mean 0.37; SD 1.33) during 2005-2025 (unit in mm).

Table 4. Decadal change in hydrologic variables (in mm) due to $L U L C C$.

\begin{tabular}{llll}
\hline Year & ET & Runoff & Baseflow \\
\hline LULC 1985 & 746.21 & 179.45 & 444.40 \\
LULC 1995 & 746.00 & 179.52 & 444.46 \\
LULC 2005 & 746.07 & 179.51 & 444.36 \\
LULC 2025 & 745.42 & 179.60 & 444.73 \\
\hline Change duration & Change in \% & \\
\hline 1985-1995 & -0.03 & 0.03 & 0.01 \\
1995-2005 & 0.01 & 0.00 & -0.02 \\
2005-2005 & -0.09 & 0.05 & 0.08 \\
\hline
\end{tabular}

Similarly, table 5(ii) shows that the monthly runoff during 1985, 1995, 2005 and 2025 ranges from 0.71$52.30,0.71-52.30,0.71-52.28$, and $0.71-52.29 \mathrm{~mm}$, respectively, with mean ( \pm standard deviation) of $14.96( \pm 19.62), 14.96( \pm 19.63), 14.96( \pm 19.63)$ and $14.97( \pm 19.63) \mathrm{mm}$, respectively. Generally, the highest and lowest runoff occurred in the months of July and December, respectively. Table 5(iii) shows that the monthly baseflow generated during

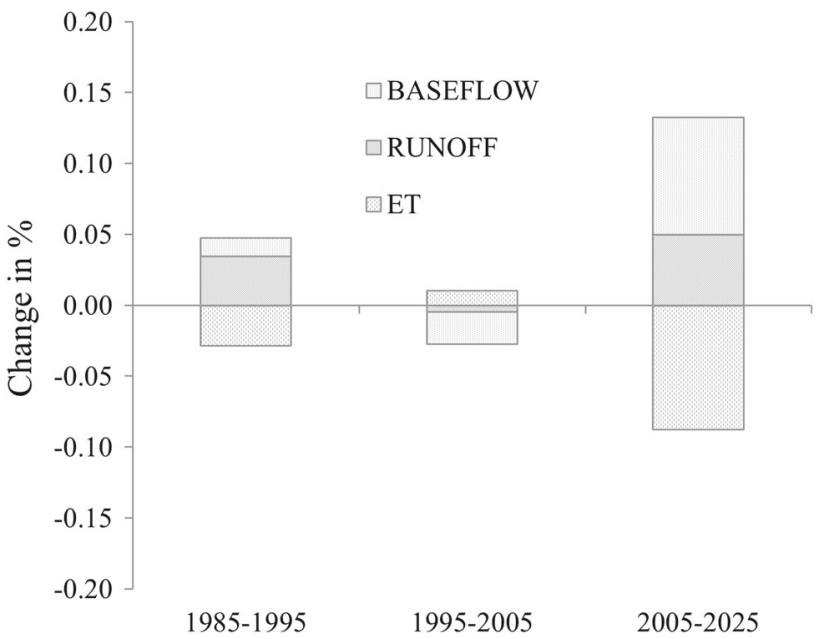

Figure 6. Change in hydrologic conditions due to LULCC during 1985-1995 and estimated change during 2005-2025 (the change shown here is the aggregated outcome of the whole MRB basin).

$1985,1995,2005$ and 2025 ranges from $0.00-148.78$, $0.00-148.77,0.00-148.76$, and $0.00-148.83 \mathrm{~mm}$, respectively, with mean ( \pm standard deviation) of 37.03 ( \pm 55.44$), 37.04( \pm 55.45), 37.03( \pm 55.43)$ 


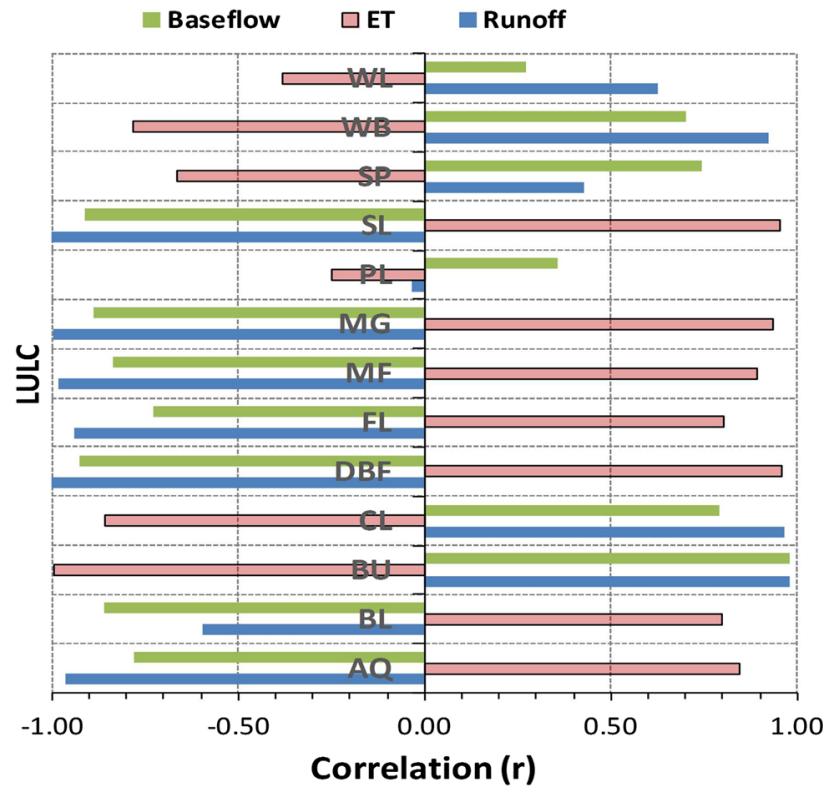

Figure 7. Correlogram between percent change in basinscale runoff, evapotranspiration and baseflow with the percent change in a specific LULC (correlation with $|r|>0.5$ is treated as significant).

and $37.06( \pm 55.48) \mathrm{mm}$, respectively. The highest and lowest runoff were observed in the months of September and February, respectively. An overall decrease was observed in ET during the study period (table 4). The decrease in ET was observed to be $0.03 \%$ during 1985-1995; however, a slight increase in ET with $0.01 \%$ was observed during 1995-2005. In contrast to ET, runoff and baseflow showed an overall increase during the study period with an increase of 0.03 and $0.01 \%$ within the years 1985-1995, respectively. Similarly, a slight decrease in runoff and baseflow with a value of $<0.01$ and $0.02 \%$ were observed during the period 1995-2005, respectively (figure 9). During 2005-2025, the expected change in ET would be varying from -0.33 to $0.45 \%$; whereas these ranges for runoff and baseflow would be -0.01 to $0.36 \%$ and -0.50 to $1.04 \%$, respectively.

It can be summarized from figure 9, showing the seasonal variation of hydrological components in the study area that the ET and run off are more prominent during pre-monsoon season (Jan, Feb, Mar, and Apr) than the monsoon and postmonsoon seasons. Due to higher precipitation, sudden increases in hydrological components were observed during the monsoon season, which continues up to the mid post-monsoon season and again this crest goes down in winters. The range of monthly ET varied from a minimum of nearly $18.30 \mathrm{~mm}$ in April to a maximum of $113.36 \mathrm{~mm}$ in July (table 5i). The runoff varied from 0.45 $\mathrm{mm}$ in December to $52.30 \mathrm{~mm}$ in July (table 5i). The range of baseflow varied from a minimum of $\sim 0 \mathrm{~mm}$ in April to a maximum of nearly 148.78 mm in August (table 5iii). Very minor changes were observed in the monthly hydrological components that varied from negative to positive units owing to decrease and increase in particular components, respectively. The overall range of seasonal ET varied from 609.85 to $973.85 \mathrm{~mm}$, whereas runoff varied from 49.77 to $443.7 \mathrm{~mm}$ and baseflow varied from 22.77 to $1044.16 \mathrm{~mm}$.

The decrease in ET, runoff and baseflow during pre-monsoon season was due to the dry period. During the crop growing season, the LAI is higher leading to more canopy transpiration in contrast to low LAI in dry season resulting in low canopy evaporation causing lower ET and viceversa. The lower value of baseflow during the dry season was observed since the deep store of water is exploited by forests with deep roots and human use; whereas, during monsoon, forest land use facilitates deep recharge of soil water leading to higher baseflow. Decadal changes in hydrological components revealed that the higher changes in relative percent difference are prominent during pre-monsoon rather than monsoon and post-monsoon seasons. The impact of deforestation rate on seasonal change in evaporation during 1985-1995 was higher as compared to 1995-2005 during monsoon season. This change in ET positively influenced the runoff and baseflow.

In the pre-monsoon season, the rate of relative percent difference is directly related to the rate of deforestation. More fluctuation in relative percent difference in ET during 1985-1995 was due to higher deforestation rate. The magnitude of LULCC is higher during 1985-1995 as compared to 1995-2005 resulting in comparatively higher difference in the changes. Seasonal changes in runoff followed the same pattern for all the decades. The pattern was also same for the relative percent difference for all the decades, i.e., less than $0(-$ ve) in pre-monsoon and little higher than $0(+$ ve) in postmonsoon. During pre-monsoon season with low runoff, the relative percent difference was higher, whereas during post-monsoon, this difference was quite less. With sufficient water availability, the LULCC impact got suppressed for both the ET and runoff in monsoon and post-monsoon due to overexpression of climate variables, such as, precipitation, leading to smooth curve. With the future predicted LULC scenario, the high deforestation 

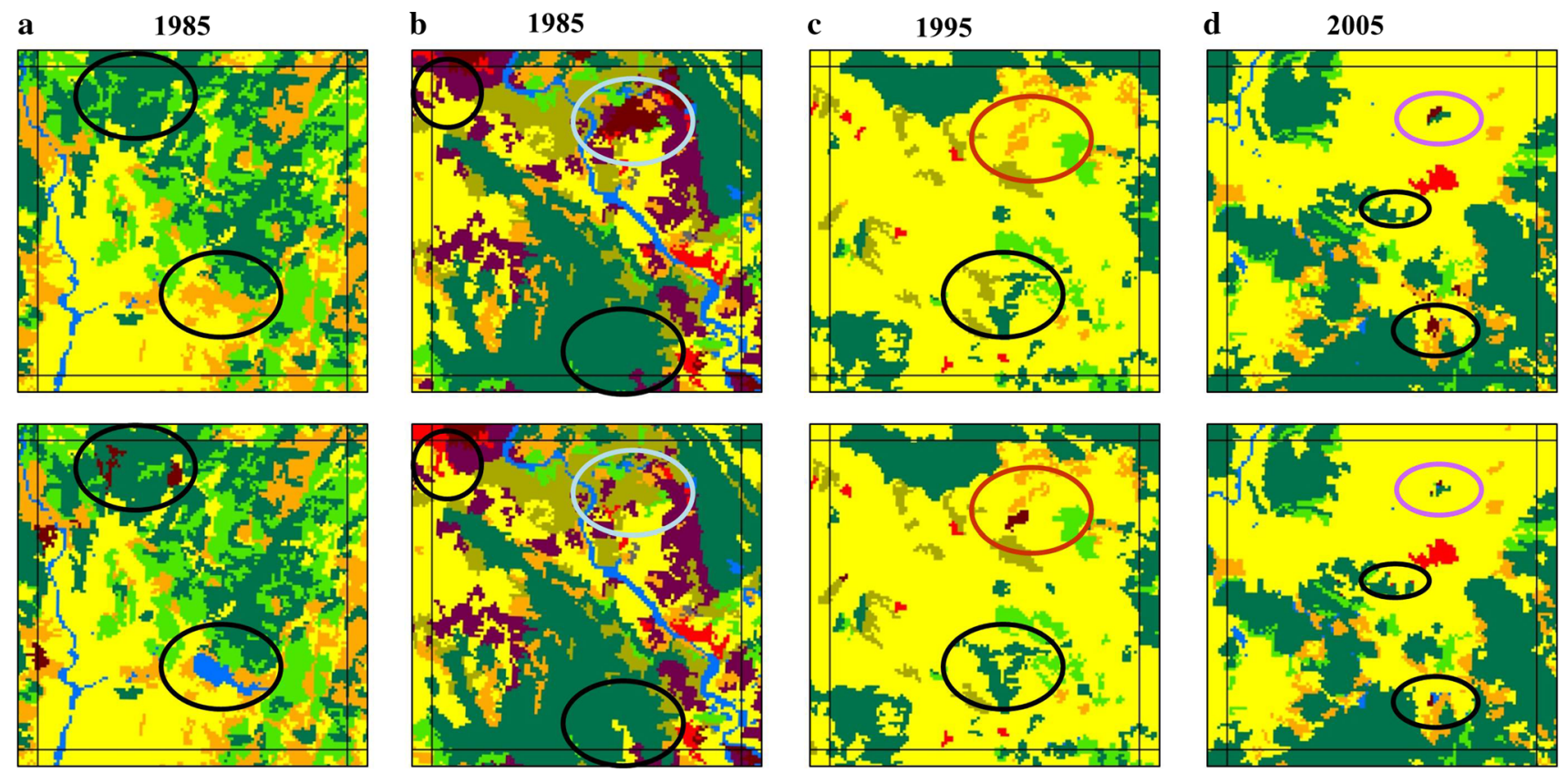

1995

2005

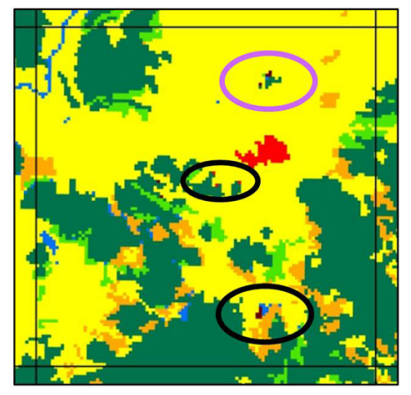

2025

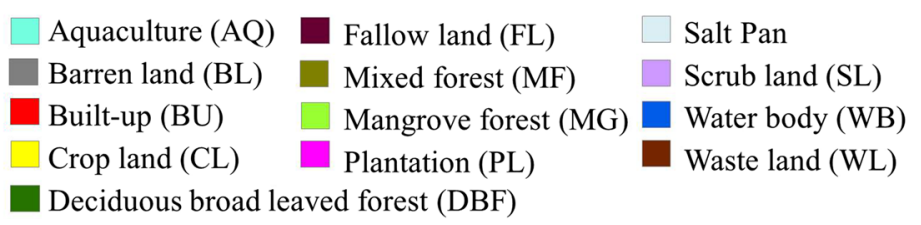

Figure 8. Impact of LULCC on ET. (a) Forest conversion to non-forest (i.e., scrubland and mixed forest changed to waterbody and fallow land) reduced the overall ET by $15.05 \mathrm{~mm}$ and increased the runoff and baseflow by 1.98 and $9.63 \mathrm{~mm}$, respectively during 1985-1995; (b) Fallow land and deciduous broadleaved forest changed to plantation, cropland and builtup increased the overall ET by $0.35 \mathrm{~mm}$ and runoff by $0.02 \mathrm{~mm}$, and decreased baseflow by $0.32 \mathrm{~mm}$ during $1985-1995$; (c) Deciduous broadleaved forest, mixed forest and cropland changed to plantation, fallow land, built-up and cropland reduced the overall ET by $1.08 \mathrm{~mm}$ and increased the runoff and baseflow by 0.13 and $0.91 \mathrm{~mm}$, respectively during 1995-2005; (d) Projected change of deciduous broadleaved forest, fallow land and scrubland to cropland and built-up would reduce the overall ET by $-2.25 \mathrm{~mm}$ and would increase runoff and baseflow by 0.59 and $1.14 \mathrm{~mm}$, respectively during 2005-2025.

rates were predicted during 2005-2025; and hence, the decrease in evaporation and overall ET with an increased trend of runoff and baseflow.

Overall, a decrease in ET was observed at some locations in the study area, primarily due to the conversion of forest or cropland to wasteland, builtup or shrub land. In contrast, increases in ET were observed at other places, primarily due to increase in plantation and cropland areas. Therefore, the increase in ET cancelled out the decrease in ET at the basin scale considerably. The same compensation effects were also observed for runoff and baseflow. The results of the study suggest that the small scale LULC changes may not extensively impact hydrological components at the basin scale, particularly when the compensation effects are prominent. However, hydrologic impacts of LULC change might be useful in a basin undergoing large scale LULC changes (e.g., considerable deforestation and urbanization) with little or no compensation effects.

It can be surmised from the above analysis that, during 2005-2025, even though the change in runoff and ET would be less significant with about -0.33 to $0.45 \%$ and -0.01 to $0.36 \%$, respectively, due to the LULC changes, these values could be significant because of the large basin area. Conversely, from this analysis, it can be understood that the recurrent high magnitude flood events occurring in the basin recently may not be much influenced by the LULC change at the basin-scale. However, the occurrence of these flood extremes could be attributed to the rainfall extremes by which rainfalls with high intensities occur within a short span of time. Moreover, due to the encroachment of the river floodplains by constructing buildings and other establishments and obstruction of natural stream lines, the runoff generated from different 
Table 5. Monthly changes in (i) ET, (ii) runoff and (ii) baseflow due to LULCC.

\begin{tabular}{|c|c|c|c|c|c|c|c|}
\hline & \multicolumn{4}{|c|}{ Value in $\mathrm{mm}$} & \multicolumn{3}{|c|}{ Change in \% } \\
\hline & 1985 & 1995 & 2005 & 2025 & 1985-1995 & 1995-2005 & 2005-2025 \\
\hline \multicolumn{8}{|l|}{ (i) } \\
\hline Jan & 37.07 & 37.17 & 37.19 & 37.36 & 0.27 & 0.05 & 0.45 \\
\hline Feb & 45.32 & 45.34 & 45.37 & 45.49 & 0.06 & 0.06 & 0.27 \\
\hline Mar & 26.31 & 26.40 & 26.41 & 26.43 & 0.35 & 0.04 & 0.06 \\
\hline Apr & 18.30 & 18.35 & 18.35 & 18.35 & 0.24 & -0.01 & 0.05 \\
\hline May & 31.99 & 31.99 & 31.99 & 31.98 & 0.02 & 0.01 & -0.04 \\
\hline Jun & 47.09 & 47.05 & 47.03 & 46.99 & -0.10 & -0.03 & -0.08 \\
\hline Jul & 113.36 & 113.25 & 113.24 & 113.07 & -0.10 & -0.01 & -0.15 \\
\hline Aug & 112.93 & 112.87 & 112.87 & 112.72 & -0.06 & 0.01 & -0.13 \\
\hline Sep & 104.59 & 104.53 & 104.53 & 104.40 & -0.06 & 0.00 & -0.13 \\
\hline Oct & 92.36 & 92.29 & 92.30 & 92.14 & -0.08 & 0.01 & -0.18 \\
\hline Nov & 69.91 & 69.83 & 69.84 & 69.61 & -0.12 & 0.02 & -0.33 \\
\hline $\begin{array}{l}\text { Dec } \\
\text { (ii) }\end{array}$ & 46.97 & 46.93 & 46.95 & 46.88 & -0.08 & 0.04 & -0.15 \\
\hline Jan & 2.03 & 2.03 & 2.03 & 2.03 & 0.02 & -0.02 & -0.01 \\
\hline Feb & 0.71 & 0.71 & 0.71 & 0.71 & 0.02 & -0.01 & 0.05 \\
\hline Mar & 0.93 & 0.93 & 0.93 & 0.93 & -0.05 & -0.05 & 0.00 \\
\hline Apr & 0.74 & 0.74 & 0.74 & 0.74 & -0.08 & -0.10 & 0.00 \\
\hline May & 1.48 & 1.48 & 1.48 & 1.48 & -0.02 & -0.05 & 0.00 \\
\hline Jun & 12.45 & 12.45 & 12.45 & 12.45 & -0.05 & -0.02 & 0.01 \\
\hline Jul & 52.30 & 52.30 & 52.28 & 52.29 & 0.00 & -0.04 & 0.01 \\
\hline Aug & 34.06 & 34.08 & 34.08 & 34.10 & 0.06 & 0.02 & 0.05 \\
\hline Sep & 47.10 & 47.13 & 47.14 & 47.18 & 0.07 & 0.01 & 0.09 \\
\hline Oct & 25.23 & 25.24 & 25.25 & 25.27 & 0.05 & 0.02 & 0.09 \\
\hline Nov & 1.97 & 1.97 & 1.97 & 1.97 & 0.05 & 0.03 & 0.04 \\
\hline $\begin{array}{l}\text { Dec } \\
\text { (iii) }\end{array}$ & 0.45 & 0.45 & 0.45 & 0.45 & 0.05 & 0.00 & 0.36 \\
\hline Jan & 0.00 & 0.00 & 0.00 & 0.00 & 0.00 & 0.31 & 0.06 \\
\hline Feb & 0.01 & 0.01 & 0.01 & 0.01 & 0.01 & 0.03 & -0.34 \\
\hline Mar & 0.00 & 0.00 & 0.00 & 0.00 & -0.55 & 0.00 & 0.00 \\
\hline Apr & 0.00 & 0.00 & 0.00 & 0.00 & -4.81 & 0.76 & -0.50 \\
\hline May & 0.00 & 0.00 & 0.00 & 0.00 & -1.21 & -0.47 & -0.20 \\
\hline Jun & 0.77 & 0.77 & 0.77 & 0.78 & -0.41 & -0.11 & 1.04 \\
\hline Jul & 84.09 & 84.01 & 83.98 & 84.01 & -0.09 & -0.04 & 0.04 \\
\hline Aug & 148.78 & 148.77 & 148.76 & 148.83 & 0.00 & -0.01 & 0.05 \\
\hline Sep & 127.17 & 127.26 & 127.24 & 127.37 & 0.07 & -0.02 & 0.11 \\
\hline Oct & 68.26 & 68.30 & 68.28 & 68.37 & 0.06 & -0.03 & 0.13 \\
\hline Nov & 15.04 & 15.05 & 15.04 & 15.07 & 0.09 & -0.03 & 0.14 \\
\hline Dec & 0.28 & 0.29 & 0.29 & 0.29 & 0.25 & -0.01 & 0.42 \\
\hline
\end{tabular}

land uses could not be effectively drained out, causing flood havoc. Furthermore, an increase in baseflow would help in groundwater recharge.

\subsection{Sensitivity of the hydrological variables due to LULC change}

A hypothetical simulation was carried out to test the model sensitivity to LULCC. The entire study area was kept as forest, cropland and plantation. In general, ET was decreased, increasing the runoff and baseflow. The overall annual ET was decreased by $11.30 \%$ due to conversion of forest to plantation, which was $17.78 \%$ in case of forest to cropland conversion. This resulted in an increase in annual runoff by 5.85 and $9.20 \%$, and annual baseflow by 18.51 and $29.58 \%$, respectively, for forest plantation and forest-cropland conversions (see supplementary table S2). These results approve the sensitivity of model performance. Frans et al. (2013), Mao and Cherkauer (2009), Twine et al. (2004) also observed similar results during sensitivity 

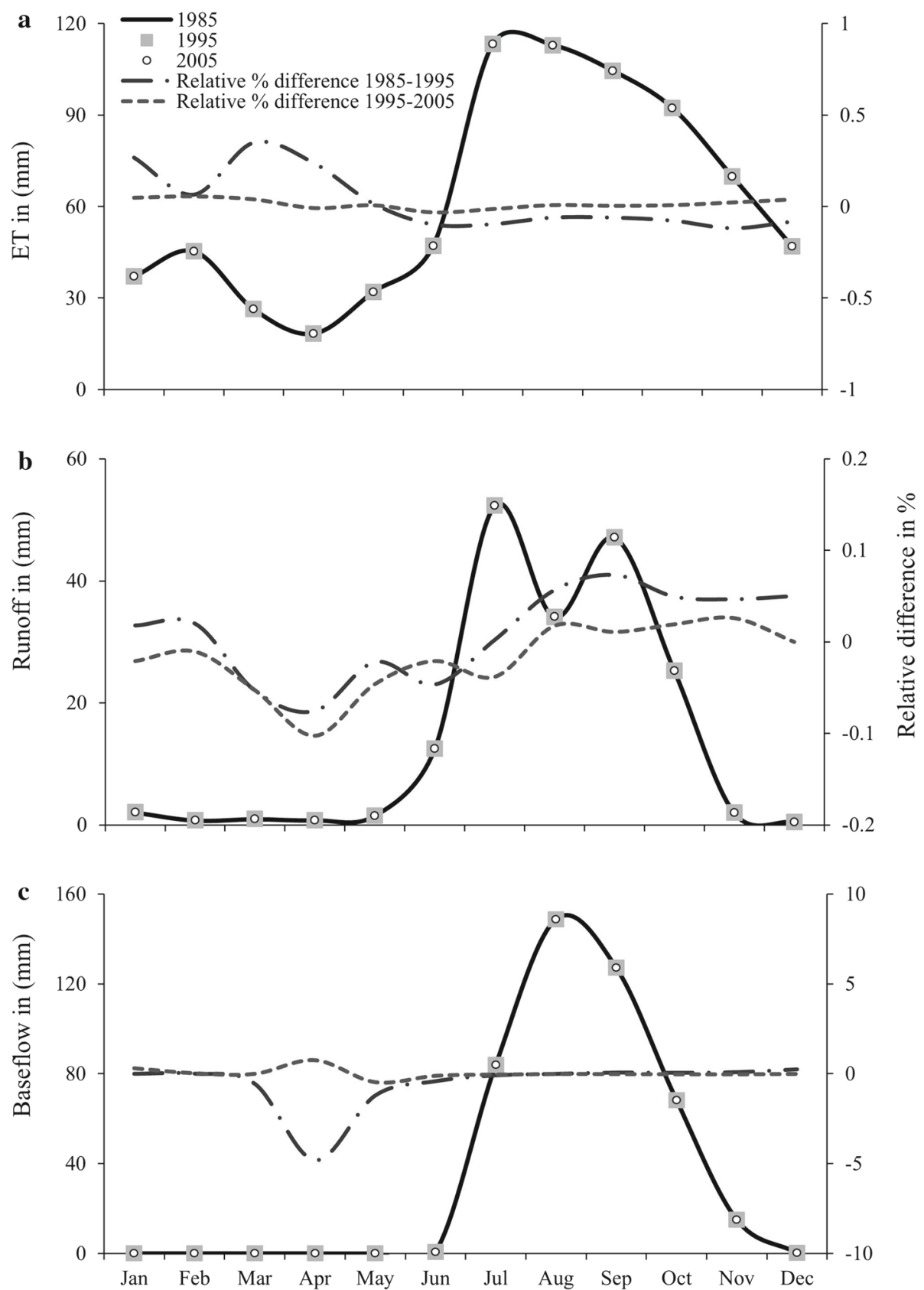

Figure 9. LULCC effect on monthly (a) ET, (b) runoff, and (c) baseflow during 1985, 1995 and 2005 (note: The legend and $\mathrm{x}$-axis scale of are same for ET, runoff and baseflow).

analysis. The inspection of monthly variation in runoff compared to precipitation reveals that the variation of runoff followed the same trend as precipitation. The overall pattern of the relative percent difference in runoff generation for all decades seems to follow the same trend, i.e., negative values in pre-monsoon and nearly equal to or higher than 0 values (+ve) in monsoon and post-monsoon seasons. However, the relative percent difference was showing a prominent dip during 1995-2005 as compared to 1985-1995. During pre-monsoon season with low runoff, the relative percent difference is higher, whereas in monsoon and postmonsoon this difference is quite less (figure 9). The changes in evapotranspiration (ET) during 1985-1995 and 1995-2005 have been plotted with the relative percent difference in figure 9. Unlike the runoff, ET is not following the same trend with precipitation. During pre-monsoon season with low precipitation, the relative percent difference is higher, whereas during the monsoon and post-monsoon seasons with high precipitation, this 
difference is quite less. Similarly, the impact of LULCC on ET is high during pre-monsoon season than the monsoon and post-monsoon seasons.

The assessment of the hydrologic effects of LULC change is a vital pre-requisite for water resources development and management. Implementation of physical and distributed model VIC requires a detailed description of vegetation and soil parameters, but can precisely identify the modifications in hydrological regime due to LULC changes. Nevertheless, the assessment of hydrologic impacts of LULC change is a challenging task mainly due to the fact that the observed or simulated changes in hydrological components are combined impact of climate variability, LULC change and human interventions (such as regulation of river flow through dams and barrages). Although the procedure which was adopted in this study to simulate hydrological responses from the study area is reasonable in order to identify the impacts of LULC change, an analysis can be performed in future studies to assess the relative contributions of LULC change and climate variability to changing hydrological responses.

\section{Conclusions}

The hydrological modeling using the VIC macroscale model carried out in this study clearly brought out the significant impact of LULCC on the hydrological components of evapotranspiration, runoff and baseflow at basin-scale, dictating the model ability to successfully accommodate all components of the environmental and landscape variables. The overall annual ET was decreased by $11.30 \%$, compensated by an increase in annual runoff by 5.85 and $9.20 \%$, and annual base flow by 18.51 and $29.58 \%$, respectively; is well corroborated with the conversion of forest to plantation, forest to cropland in the river basins. This study indicates that the deforestation at the cost of urbanization and cropland expansions leads to the decrease in the overall ET with an increase in runoff and baseflow. This study has provided valuable insights in the perspective of the subsequent changes in hydrological components as a result of LULCC for future prediction, which can be useful in developing management policies to conserve the forests in more intelligent and scientific way. For calibration and validation, the gauging sites were selected in the upstream areas of the rivers which were showing good agreement with the simulated streamflow. However, the downstream gauging sites might bias the estimation due to the dam management policies which were not included in the present study, which could be scope of a future study by including the lake module in the VIC framework. The LULC have clear impact on the watershed hydrology altering the runoff and streamflow discharges, especially in the studied basins, where monsoon flood and water inundation are regular events in past decades. However, a number of man-made structures as reservoirs and dams reduced such events. Deforestation, cropland expansion and urbanization are prominent and will continue in the upcoming decades. This study is providing insights to the future hydrological scenarios, which will offer the planners to take prior actions for sustainable water use.

\section{Acknowledgements}

Thanks are due to IIRS for all the necessary facilities provided for this research work. The ILULC-DMP modeling platform provided for LULC modeling and prediction, and their expert opinion were precious and valuable.

\section{References}

Abbott M B, Bathurst J C, Cunge J A, O'Connell P E and Rasmussen J 1986 An introduction to the European hydrological system - Systeme Hydrologique Europeen, "SHE", 1: History and philosophy of a physically-based, distributed modelling system; J. Hydrol. 87(1) 45-59.

Aggarwal S P, Garg V, Gupta P K, Nikam B R and Thakur P K 2012 Climate and LULC change scenarios to study its impact on hydrological regime; Int. Arch Photogram Rem. Sen. Spa. Inf. Sci. (ISPRS) 39 B8.

Alcamo J and Henrichs T 2002 Critical regions: A modelbased estimation of world water resources sensitive to global changes; Aquat. Sci. 64(4) 352-362.

Alcamo J, Grassl H, Hoff H, Kabat P, Lansigan F, Lawford R, Lettenmaier D, Lévêque C, Meybeck M, Naiman R and Pahl-Wostl C 2005 The global water ssystem project: Science framework and implementation activities; Earth System Science Partnership, Bonn, Germany.

Arnold J G, Srinivasan R, Muttiah R S and Williams J R 1998 Large area hydrologic modelling and assessment. Part 1: Model development; J. Am. Water Resour. Assoc. 34(1) 73-89.

Asrar G and Dozier J 1994 EOS: Science Strategy for the Earth Observing System; Woodbury, NY, American Institute of Physics.

Babar S and Ramesh H 2015 Streamflow response to land use-land cover change over the Nethravathi River Basin, 
India; J. Hydrol. Eng. 20(10), https://doi.org/10.1061/ (ASCE)HE1943-55840001177.

Behera M D, Tripathi P, Das P, Srivastava S K, Roy P S, Joshi C, Behera P R, Deka J, Kumar P, Khan M L, Tripathi O P, Dash T and Krishnamurthy Y V N 2018 Remote sensing based deforestation analysis in Mahanadi and Brahmaputra river basin in India since 1985; J. Environ. Manag. 206 1192-1203.

Beyene T, Lettenmaier D P and Kabat P 2010 Hydrologic impacts of climate change on the Nile River basin: Implications of the 2007 IPCC scenarios; Clim. Chang. 100(3-4) 433-461.

Bhagwat P P and Maity R 2013 Hydroclimatic streamflow prediction using least square-support vector regression ISH; J. Hydrol. Eng. 19(3) 320-328.

Bhattacharya T, Aggarwal S P and Garg V 2013 Estimation of water balance components of Chambal River basin using a macroscale hydrology model; Int. J. Sci. Res. Pub. 3(2) 1-6.

Bonan G B, Pollard D and Thompson S L 1992 Effects of boreal forest vegetation on global climate; Nature $\mathbf{3 5 9}$ 716-718, https://doi.org/10.1038/359716a0.

Bosch J M and Hewlett J D 1982 A review of catchment experiments to determine the effect of vegetation changes on water yield and evapotranspiration; J. Hydrol. 55 3-23.

Brown T C 2000 Projecting US freshwater withdrawals; Water Resour. Res. 36(3) 769-780.

Calder I R 1992 Water Use of Eucalypts - A Review (No CONF-9102202-); John Wiley and Sons, New York, NY (United States).

Chahine M T 1992 The hydrologic cycle and its influence on climate; Nature 359 373-380.

Collischonn B, Collischonn W and Tucci CE 2008 Daily hydrological modeling in the Amazon basin using TRMM rainfall estimates; J. Hydrometeorol. 360(1) 207-216.

Cosby B J, Hornberger G M, Clamp R B and Ginn T R 1984 A statistical exploration of the relationships of soil moisture characteristics to the physical properties of soils; Water Resour. Res. 20(6) 682-690.

Dadhwal V K, Aggarwal S P and Mishra N 2010 Hydrological simulation of Mahanadi River basin and impact of land use/land cover change on surface runoff using a macro scale hydrological model; ISPRS TC VII Symposium, Vienna, Austria, IAPRS, Vol XXXVIII, Part 7B.

Defries R S, Bounoua L and Collatz G J 2002 Human modification of the landscape and surface climate in the next fifty years; Global Change Biol. 8 438-458, https://doi. org/10.1046/j1365-2486200200483x.

Dhami B S and Pandey A 2013 Comparative review of recently developed hydrologic models; J. Indian Water Resour. Soc. 33(3) 34-42.

Dietz A, Künzer C, Gessner U and Dech S 2012 Remote sensing of snow - a review on available methods; Int. J. Remote Sens. 33 (13) 4094-4134.

Dumenil L and Todini E 1992 A rainfall-runoff scheme for use in the Hamburg climate model; In: Advances in Theoretical Hydrology; Eur. Geop. Soc. Ser. Hydrol. Sci. 1 $129-157$.

Favreau G, Caelaere B, Massuel, S, Leblanc M, Boucher M, Boulain N and Leduc C 2009 Land clearing, climate variability, and water resources increase in semi-arid southwest Niger: A review; Water Resour. Res. 45 7, https://doi.org/10.1029/2007WR006785.

Frans C, Istanbulluoglu E, Mishra V, Munoz-Arriola F and Lettenmaier D P 2013 Are climatic or land cover changes the dominant cause of runoff trends in the Uer Mississii River Basin; Geophys. Res. Lett. 40(6) 1104-1110.

Gao H et al. 2009 Water budget record from variable infiltration capacity (VIC) model algorithm theoretical basis document; Dept. Civil and Environmental Eng., Univ. Washington, Seattle, WA, 09-18.

Garg V, Khwanchanok A, Gupta P K, Aggarwal S P, Kiriwongwattana K, Thakur P K and Nikam B R 2012 Urbanisation effect on hydrological response: A case study of Asan River Watershed, India; J. Environ. Earth Sci. 2(9) 39-50.

Geethalakshmi V, Kitterod N O and Lakshmanan A 2008 A literature review on modeling of hydrological processes and feedback mechanisms on climate; CLIMARICE Report No. 2, $48 \mathrm{~s}$.

Henderson-Sellers A, Dickinson R E, Durbridge T, Kennedy P, McGuffie K and Pitman A 1993 Tropical deforestation: Modeling local- to regional-scale climate change; J. Geophys. Res. Atmos. 98(D4) 7289-7315, https://doi.org/10. 1029/2JD02830.

Koster R D, Dirmeyer P A, Guo Z C, Bonan G, Chan E, Cox P, Gordon C T, Kanae S, Kowalczyk E, Lawrence D, Liu P, Lu C H, Malyshev S, McAvaney B, Mitchell K, Mocko D, Oki T, Oleson K, Pitman A, Sud Y C, Taylor C M, Verseghy D, Vasic R, Xue Y K, Yamada T and Team G 2004 Regions of strong coupling between soil moisture and precipitation; Science 305 1138-1140.

Lawrence K T, Sosdian S, White H E and Rosenthal Y 2010 North Atlantic climate evolution through the Plio-Pleistocene climate transitions; Earth Planet. Sci. Lett. 300(3) 329-342.

Li L, Hong Y, Wang J H, Adler R F, Policelli F S, Habib S, Irwn D, Korme T and Okello L 2009a Evaluation of the real-time TRMM-based multi-satellite precipitation analysis for an operational flood prediction system in Nzoia Basin, Lake Victoria; Africa Nat. Hazards 50 109-123, https://doi.org/10.1007/s11069-008-9324-5.

Li Z, Liu W Z, Zhang X C and Zheng F L 2009b Impacts of land use change and climate variability on hydrology in an agricultural catchment on the Loess Plateau of China; J. Hydrol. 377 35-42, https://doi.org/10.1016/ jjhydrol200908007.

Liang X, Lettenmaier D P, Wood E F and Burges S J 1994 A simple hydrologically based model of land surface water and energy fluxes for GSMs; J. Geophys. Res. 99(D7) 14,415-14,428.

Lohmann D, Nolte-Holube R and Raschke E 1996 A large-scale horizontal routing model to be coupled to land surface parametrization schemes; Tellus $48(\mathrm{~A})$ 708-721.

Lohmann D, Raschke E, Nijssen B and Lettenmaier D P 1998 Regional scale hydrology: II Application of the VIC-2L model to the Weser River, Germany; Hydrol. Sci. J. 43(1) $143-158$.

Lorup J K, Refsgaard J C and Mazvimari D 1998 Assessing the effect of land use change on catchment runoff by combined use of statistical tests and hydrological modelling: Case studies from Zimbabwe; J. Hydrol. 205 147-163. 
Mao D and Cherkauer K A 2009 Impacts of land-use change on hydrologic responses in the Great Lakes region; $J$. Hydrol. 374(1-2) 71-82.

Marengo J A 2006 On the hydrological cycle of the Amazon Basin: A historical review and current state-of-the-art; Rev. Bras. Meteorol. 21(3) 1-9.

Markstrom S L, Regan R S, Hay L E, Viger R J, Webb R M T, Payn R A and LaFontaine J H 2015 PRMS-IV, the precipitation-runoff modeling system; Ver. 4, US Geological Survey Techniques and Methods.

Mishra N 2008 Macroscale hydrological modelling and impact of land cover change on streamflows of the Mahanadi River Basin; M. Tech. dissertation, Indian Institute of Remote Sensing (ISRO).

Muñoz-Arriola F, Avissar R, Zhu C and Lettenmaier D P 2009 Sensitivity of the water resources of Rio Yaqui Basin, Mexico, to agriculture extensification under multiscale climate conditions; Water Resour. Res. 45(11), https://doi. org/10.1029/2007WR006783.

Nash J E and Sutcliffe J V 1970 River flow forecasting through conceptual models. Part I: A discussion of principles; J. Hydrol. 10 282-290.

Patidar N and Behera M D 2018 How significantly do land use and land cover (LULC) changes influence the water balance of a river basin? A study in Ganga river basin, India; Proc. Nat. Acad. Sci., India. Sect. A. Phis. Sci., https://doi.org/10.1007/s40010-017-0426-x.

Pielke R A 2005 Land use and climate change; Science 310(5754) 1625-1626.

Roy P S et al. 2015 Development of decadal (1985-19952005) land use and land cover database for India; Remote Sens. 7(3) 2401-2430.

Singh V K 2014 An algorithm development using agentbased modeling and simulation for land use land cover change under geospatial framework; Doctoral dissertation, Indian Institute of Remote Sensing (ISRO), Dehradun, 90 .

Schilling K E 2005 Relation of baseflow to row crop intensity in Iowa; Agr. Ecosyst. Environ. 105(1) 433-438.

Schilling K E, Jha M K, Zhang Y K, Gassman P W and Wolter C F 2008 Impact of land use and land cover change on the water balance of a large agricultural watershed: Historical effects and future directions; Water Resour. Res. 44(7), https://doi.org/10.1029/2007WR006644.

Seneviratne S I, Corti T, Davin E L, Hirschi M, Jaeger E B, Lehner I, Orlowsky B and Teuling A J 2010 Investigating soil moisture-climate interactions in a changing climate: A review; Earth-Sci. Rev. 99(3) 125-161, https://doi.org/ 10.1016/jearscirev201002004.
Shi X, Wild M and Lettenmaier D P 2010 Surface radiative fluxes over the pan-Arctic land region: Variability and trends; J. Geophys. Res. Atmos. 115(D22), https://doi. org/10.1029/2010JD014402.

Shukla S, Steinemann A C and Lettenmaier DP 2011 Drought monitoring for Washington State: Indicators and applications; J. Hydrometeorol. 12(1) 66-83.

Tang Q, Gao H, Lu H and Lettenmaier D P 2009 Remote sensing: Hydrology; Prog. Phys. Geog. 33 490-509.

Tang Q, Gao H, Yeh P, Oki T, Su F and Lettenmaier D P 2010 Dynamics of terrestrial water storage change from satellite and surface observations and modeling; J. Hydrometeorol. 11(1) 156-170.

Twine T E, Kucharik C J and Foley J A 2004 Effects of land cover change on the energy and water balance of the Mississippi river basin; J. Hydrometeorol. 5(4) 640655.

Vörösmarty C, Lettenmaier D, Leveque C, Meybeck M, Pahl-Wostl C, Alcamo J, Cosgrove W, Grassl H, Hoff H, Kabat P and Lansigan F 2004 Humans transforming the global water system; EOS Trans. Am. Geophys. Union 85(48) 509-514.

Wagner P D, Kumar S and Schneider K 2013 An assessment of land use change impacts on the water resources of the Mula and Mutha rivers catchment upstream of Pune, India; Hydrol. Earth Syst. Sci. 17(6) 2233-2246, https:// doi.org/10.5194/hess-17-2233-2013.

Wang L and Qu J J 2009 Satellite remote sensing applications for surface soil moisture monitoring: A review; Front. Earth Sci. China 3 237-247.

White R, Uljee I and Engelen G 2012 Integrated modelling of population, employment and land-use change with a multiple activity-based variable grid cellular automaton; Int. J. Geogr. Inf. Sci. 26(7) 1251-1280.

Xu X, Li J and Tolson B A 2014 Progress in integrating remote sensing data and hydrologic modeling; Progr. Phys. Geogr. 38(4) 464-498, https://doi.org/10.1177/ 0309133314536583.

Yuan F, Xie Z H and Liu Q 2004 An application of the VIC-31 land surface model and remote sensing data in simulating streamflow for the Hanjiang river basin; Can. J. Remote Sens. 30(5) 680-690.

Zhang Y K and Schilling K E 2006 Effects of land cover on water table, soil moisture, evapotranspiration, and groundwater recharge: a field observation and analysis; J. Hydrol. 319(1) 328-338.

Zhao R J, Zhang Y L and Fang L R 1980 The Xinanjiang model; In: Hydrological Forecasting Proceedings; Oxford $129351-356$. 